\title{
舌癌64症例の治療成績と臨床病理学的検討
}

\author{
足立尚・横江義彦・野瀬将洋・德地正純
}

村上賢一郎・兵 行忠・飯塚忠彦

\section{Clinico-pathological study and prognosis of 64 tongue cancer}

\author{
Hisashi Adach - Yoshihiko Yokoe - Masahiro Nose - Masazumi Tokuchi \\ Ken-Ichiro Murakami • Yukitada Hyo - Tadahiko Izuka
}

\begin{abstract}
Department of Oral and Maxillofacial Surgery at Kyoto University Hospital and the following results were obtained.

1) The 64 patients consisted of 35 males and 29 females with an age average of 53.8. Pain was the most frequent chief complaint, and $48.4 \%$ of them visited our clinic within 3 months after onset of the symptom.

2) 63 of 64 cases were pathologically diagnosed as squamous cell carcinoma. In stage classification, Stage I : 2 cases, Stage II : 20 cases, Stage III : 27 cases, Stage IV: 15 cases.

3) $73 \%$ of 64 cases were treated by surgery and radiotherapy. Pull through operation was the most frequent in surgery and external radiotherapy was given in almost all the cases post operatively. Prophylactic upper neck dissection was done in $73.7 \%$ of 38 cases.

4) The accumulated 5-year survival rate was $65.6 \%$ in all cases, and $73.9 \%$ in 47 cases of surgery + radiotherapy group. On the other hand, it was $55.6 \%$ in 6 cases of surgery group, and $35.1 \%$ in 10 cases of radiotherapy group.

5) The higher the stage and the lower the histological differentiation, the lower the accumulated 5-year survival rate tended to be.
\end{abstract}

Key words: tongue cancer (舌癌), survival rate (生存率), clinico-statistical study (臨床統計 学的検剖)

緒言

舌癌は，䪽口腔腫瘍の中でも比較的発生頻度の高い悪 性腫瘍の一つである。従来より舌癌の治療は, 主として 外科療法あるいは放射線療法のいずれかが選択されてき たが，近年では舌の機能面を重視する考えから，組織内 照射, 化学療法, 免疫療法なとが積極的に行わ机るよら

口腔外科受教室

（主任：饭塚忠彦教授）

Department of Oral and Maxillofacial Surgery, Faculty of Medicine, Kyoto University (C'hief:

Prof. Tadahiko Iizuka)

受付日：平成元年 3 月 23 日
になり，5年生存率で $60 \%$ を越える治療成績がみられる よらになってきたが，必ずしも満足できるものではな い. 当科では従来より外科療法を主体として舌癌の治療 にあたってきており今後の治療方針の一助とするため に, 過去 13 年間の舌癌 1 次症例を対象に, その臨床所 見，治療法および治療成績について検討したので報告す る.

\section{研究対象および方法}

1973年（昭和48年）1月から1985年（昭和60年）12月 までの13年間に, 京都大学医学部附属病院口腔外科を受 診した舌癌の総症例数81例中 1 次症例であった64例を今 回の研究対象とした。なお有郭乳頭より後方の舌癌は, 
男 性：35例

女 性：29 例

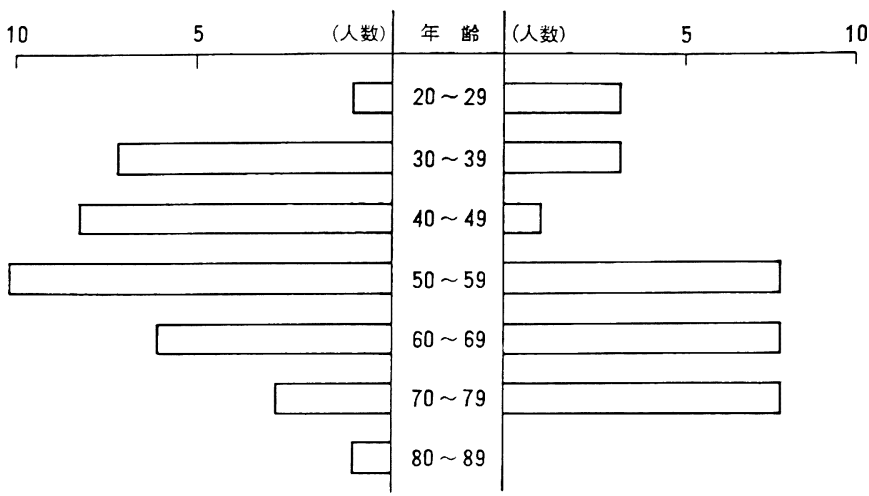

図 1 性別・年龄別症例数

1978年 UICC 分類1) に従い中咽頭癌として今回の研究 対象からは除外した。これらを対象に臨床統計的観察を 行った。検討内容として, 性別, 年龄, 初発症状, 来院 までの期間と経路の項目について行い，また，腫瘍の発 生部位, 発育様式, TNM 分類, Stage 分類, 治療法, 治療成績および, 病理組織学的分類, 分化度について検 討した。加えて，頸部リンパ節転移の臨床診断と組織診 の比較を行った。

\section{1. 性別および年齢別（図 1)}

性別では男性35例，女性29例であり，男女比は1.2:1 で，わずかに男性に多く認められた。年齢は20藏から81 歳までに分布しており，平均年㱓は53.8歳であり，男性 は51.5藏，女性は56.7歳で，男性では30歳代より増加傾 向があり，50歳代が最も多かったのに対して，女性では 50〜70藏代の高年路層に集中していた。

\section{2. 初発症状（表1）}

初発症状は, 疼痛が最も多く, 29例 $(45.3 \%)$ と半数 近くを占め, その内訳は接触痛19例, 自発痛10例であっ

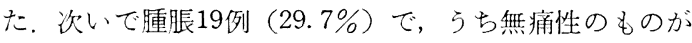
15例を占めた。続いて，潰瘍形成 7 例 $(10.9 \%)$, 不快 感 6 例 $(9.4 \%)$ の順であった。

\section{3. 初発症状から来院までの期間と経路（表 2，3）}

初発症状を自覚してから当科来院までの期間をみる と, 1 か月以内に来院した症例は合せて13例 $(20.3 \%)$, また 3 か月までには約半数の31例が，そして6か月まで には71.9\%に当る46例が来院していた。

当科への来院経路をみると，幽科医師からの紹介が 25 例 $(39.1 \%)$ と最も多く，その内訳は開紧医16例，病院 の歯科口腔外科 9 例であった。次いで他科からの紹介は 23例 $(35.9 \%)$ で，その中でも内科，外科が多く，その 他では整形外科, 皮泞科, 眼科, 婦人科が各 1 例であっ た。当科に直接来院した症例は16例（25.0\%）であった。
表 1 初発症例別分類

\begin{tabular}{|c|c|c|}
\hline \multicolumn{2}{|c|}{ 初発症状 } & 症例数 $(\%)$ \\
\hline 疼 & 痛 & $29 \quad(45.3)$ \\
\hline 接 触 & 痛 & 19 \\
\hline 自 発 & 痛 & 10 \\
\hline 腫 & 脹 & $19 \quad(29.7)$ \\
\hline 有 痛 & 性 & 4 \\
\hline 無 痛 & 性 & 15 \\
\hline 潰 瘍 形 & 成 & $7 \quad(10.9)$ \\
\hline 不＼cjkstart快 & 感 & $6(9.4)$ \\
\hline 白 & 斑 & $2(3.1)$ \\
\hline 知 覚 異 & 常 & $1(1.6)$ \\
\hline 計 & & $64(100.0)$ \\
\hline
\end{tabular}

表 2 米院までの期間

\begin{tabular}{c|rc}
\hline 期 間 & 症例数 $(\%)$ \\
\hline$\sim 2$ 週 & 2 & $(3.1)$ \\
$\sim 1$ か月 & 11 & $(17.2)$ \\
$\sim 3$ か月 & 19 & $(29.7)$ \\
$\sim 6$ か月 & 14 & $(21.9)$ \\
$\sim 1$ 年 & 7 & $(10.9)$ \\
$\sim 3$ 年 & 9 & $(14.1)$ \\
3 年 & 2 & $(3.1)$ \\
\hline 計 & 64 & $(100.0)$ \\
\hline
\end{tabular}

\section{4. 発生部位別 (表 4)}

発生部位別では，舌縁が56例 $(87.5 \%)$ と大多数を占 め, 特に左右差は認められなかった。

\section{5. 発育様式別（表 5 ）}

腫瘍の発育様式を䈍津の分類 ${ }^{2)}$ に従って 6 型に分類し 
表 3 米院経路

\begin{tabular}{|c|c|c|}
\hline 経 & 路 & 症例数 $(\%)$ \\
\hline 当 & 科 & $16 \quad(25.0)$ \\
\hline 荬 & 科 & $25 \quad(39.1)$ \\
\hline 開 & 策 医 & 16 \\
\hline 病 & 院 & 9 \\
\hline 他 & 科 & $23 \quad(35.9)$ \\
\hline 内 & 科 & 9 \\
\hline 外 & 科 & 7 \\
\hline 耳 & 科 & 3 \\
\hline そ & の 他 & 4 \\
\hline \multicolumn{2}{|c|}{ 部 } & $64(100.0)$ \\
\hline
\end{tabular}

表 4 発生部位別症例数

\begin{tabular}{|c|c|c|}
\hline 部 & 位 & 症例数 $(\%)$ \\
\hline 舌 & 緣 & $56 \quad(87.5)$ \\
\hline 右 & 㑡 & 27 \\
\hline 左 & 側 & 29 \\
\hline 舌 & 下 & $6(9.4)$ \\
\hline 舌 & 背 & $2(3.1)$ \\
\hline \multicolumn{2}{|c|}{ 計 } & $64(100.0)$ \\
\hline
\end{tabular}

表 5 発育様式別症例数

\begin{tabular}{|c|c|}
\hline 発育様式 & 症例数 $(\%)$ \\
\hline 外 向 型 & $22 \quad(34.4)$ \\
\hline 白 板 型 & 10 \\
\hline 乳 頭 型 & 9 \\
\hline 肉芽 型 & 3 \\
\hline 内 向 型 & $42 \quad(65.6)$ \\
\hline 浿 瘍 型 & 35 \\
\hline 腫 瘤 型 & 6 \\
\hline びらん紅板型 & 1 \\
\hline 計 & $64(100.0)$ \\
\hline
\end{tabular}

た。混合型と思える症例もみられたが，いずれか傾向の 強い力の型に決定した。 その結果, 外向型22例に対し, 内向型が 42 例亡多数を占め, その中でも潰瘍型が 35 例と 全体の $54.7 \%$ 占めていた。

\section{6. 病理組織型・分化度別（表 6 )}

病理組織型別症例数では, 1 例の腺様漠胞癌を除く63 例のすべてが扁平上皮癌であった。病理組織標本の再検 討可能であった扁平上皮癌54症例について，その分化度 別症例数をみると，高分化型 22 例 $(40.8 \%)$ ，中分化型 18例 $(33.3 \%)$ ，低分化型14例 $(25.9 \%)$ の順であった。
表 6 分化度別症例数

\begin{tabular}{c|cc}
\hline 分化度 & \multicolumn{2}{|c}{ 症例数 $(\%)$} \\
\hline 高分化型 & 22 & $(40.8)$ \\
中分化型 & 18 & $(33.3)$ \\
低分化型 & 14 & $(25.9)$ \\
\hline 計 & $54(100.0)$ \\
\hline
\end{tabular}

表 7 T N 分類

\begin{tabular}{c|rrrr|r}
\hline & N0 & N1 & N2 & N3 & 計 \\
\hline T1 & 2 & 2 & & 1 & 5 \\
T2 & 20 & 7 & 4 & 1 & 32 \\
T3 & 16 & 2 & 4 & 5 & 27 \\
\hline 計 & 38 & 11 & 8 & 7 & 64 \\
\hline
\end{tabular}

表 8 Stage 分類

\begin{tabular}{c|rc}
\hline & 症例数 $(\%)$ \\
\hline Stage I & 2 & $(3.1)$ \\
Stage II & 20 & $(31.3)$ \\
Stage III & 27 & $(42.2)$ \\
Stage IV & 15 & $(23.4)$ \\
\hline & & $64(100.0)$ \\
\hline
\end{tabular}

表 9 治療法別 Stage 分類

\begin{tabular}{rr|rrrr|rc}
\hline & Stage & I & II & II & IV & 計 & $(\%)$ \\
\hline \multicolumn{2}{r|r}{$\mathrm{S}+\mathrm{R}$ 群 } & & 17 & 18 & 12 & 47 & $(73.4)$ \\
$\mathrm{R}$ & 群 & & 2 & 6 & 2 & 10 & $(15.6)$ \\
$\mathrm{S}$ & 群 & 2 & 1 & 2 & 1 & 6 & $(9.4)$ \\
非治 療 & & & 1 & & 1 & $(1.6)$ \\
\hline & & 2 & 20 & 27 & 15 & 64 & $(100.0)$ \\
\hline
\end{tabular}

\section{TNM 分類 (表 7)}

TNM 分類は国際対癌連合 (UIC'C)による1978年の 分類を用いた。

T分類ではT2 32例 (50\%), T3 27例 (42.2\%), T1 5 例 $(7.8 \%)$ の順で多く，N分類ではN0が38例 (59.4 \%)であり，初診時に頸部転移が越われた $\mathrm{N}+$ 症例は， 26例で $40.6 \%$ であった。M分類では初診時に肺への遌隔 転移を学たT3 N2 M1症例が1例市った。他は全てM0 症例であった。

\section{Stage 分類 (表 8 )}

Stage 分類では Stage III：27例 (42.2\%), Stage II : 20 例 $(31.3 \%)$, Stage $V: 15$ 例 $(23.4 \%)$, Stage I : 
2 例 $(3.1 \%)$ の順であった。

\section{9. 治療法別 (表 9)}

総数64例に対して施行した初回治療について検討し た。手術治療（S）としては腫瘍を含も舌切除術および 下顎骨辺縁または区域切除術が施行された。放射線治療 （R）では，組織内照射法 5 例以外は全て外照射法で行 った。照射の時期は手術治療併用症例47例中 2 例のみが 術前で，他は術後に施行されていた。線源は，小線源亡 して ${ }^{226} \mathrm{Ra},{ }^{137} \mathrm{Cs}$, 外照射では ${ }^{60} \mathrm{Co}, \mathrm{X}$ 線 (Linac), ß-tronなどが用いられた。線量は，外照射で 3,000 rads から 7,400 rads までに分布し, 平均線量は 5, $124 \mathrm{rads}$ であった。化学療法については64例中26例にBleomycin （平均投与量 $166 \mathrm{mg}$ ) が，また 15 例には Pepleomycin （平均投与量 $73.3 \mathrm{mg}$ ) などを主体とした化学療法をそ れぞれ他橑法と組合せて実施していた。また全64症例を 通じて，経口抗腫痬剂の投与を行っていたが，各症例の 投与量には著しい差があった。

総数64症例を手術治療主体の S 群, 放射線治療主体の R 群，てして，併用療法の S + R 群に分類した結果， $\mathrm{S}$ + R 群が 64 例中 47 例で73.4\% と最も多く, R 群は10 例 (15.6\%) で，その内訳は外照射 5 例，組織内照射 4 例, 併用 1 例であった。また，S 群は6 例 $(9.4 \%)$ にとどま った。非治療例の 1 例は，急激な腫瘍增大之全身状態の 患化により何ら積極的な治療の行えなかった T 2 N1 症 例である。化学療法については, 単独で根治的療法とし
て施行したものはなく，多くは手術または放射線治療の 補助療法として実施され，その投与量，期間とも幅が広 いために治療成績に際しては独立した群として検討しえ なかった。

症例の Stage 別に選択された治療をみると, Stage I の 2 症例には S 群が施行され、 Stage II, II, VVにい ては各 Stage とも， $\mathrm{S}+\mathrm{R}$ 群が最も多く施行されてい た。

i ) 腫瘍原発巣に対する手術治療の術式別分類(表10)

原発榡に対する手術は，64例中53例（82.8\%）に初回 治療時に施行しており，またこれら53例中 1 例（T1 N0 M0）を除く全例に頸部に対する手術も同時に施行 していた。術式は，口腔内より行う A）部分切除術,

表 10 原発㮐に対する手術治療の術式別

\begin{tabular}{|c|c|c|c|c|c|c|c|}
\hline & 術式 $\quad$ Stage 分類 & I & II & III & IV & 計 & $(\%)$ \\
\hline A ) & 部分切除 & 2 & 2 & 1 & & 5 & (9.4) \\
\hline B ) & 半側切除 & & 4 & 4 & & 8 & (15.1) \\
\hline C) & 口底十半側切除 & & 1 & 7 & & 8 & (15.1) \\
\hline D ) & Pull through 手術 & & 11 & 8 & 9 & 28 & $(52.8)$ \\
\hline E) & $\mathrm{D}+$ 下顎骨辺緣切除 & & & 1 & 1 & 2 & $(3.8)$ \\
\hline F ) & $\mathrm{C}+$ 下顎骨区域切除 & & & 1 & 1 & 2 & $(3.8)$ \\
\hline & 計 & 2 & 18 & 22 & 11 & 53 & $(100.0)$ \\
\hline
\end{tabular}

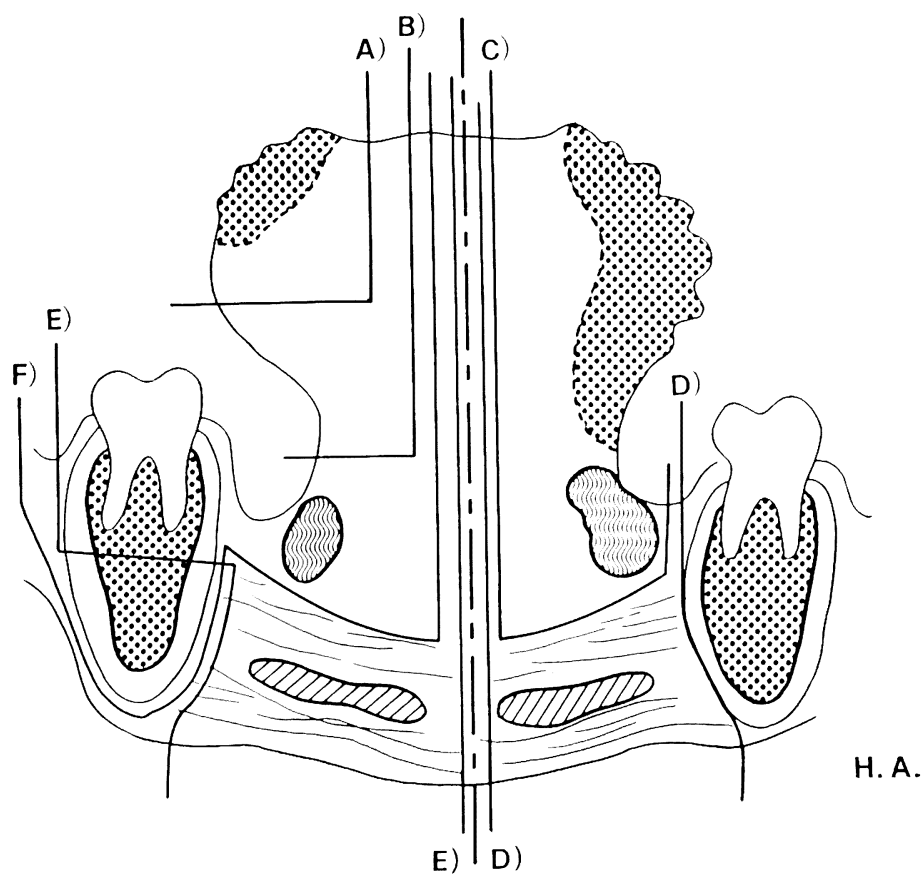

図 2 手術法 
B ) 舌半側切除術，C）口底を含めた舌半側切除術の 3 群に加兄, 頸部郭清術に連続して腫瘍組織を en bloc 切 除する，D）pull through 手術，E）下顎骨辺縁切除術 を加えた pull through 手術，F）口底を含めた舌半側 切除術に下靧骨区域切除を加えたものの6 群に分類した (図 2).

術式ではD) pull through 手術が28例で, 最も多く選 択され，手術施行例の $52.8 \%$ を占めていた（表 10）. Stage 分類との関係をみると, Stage I の 2 例には部分 切除術のみが施行され，Stage II， III，Iにおいては， D) pull through 手術が最も多く施行されていた. Stage III， IVの骨浸潤進展例 4 例に対しては，原発紧の 切除術に加之，下顎骨辺縁切除術または区域切除術が行 われており， Stage が高くなる汪ど搪大手術が施行され る傾向がみられた。

\section{ii ) 頸部手術（表 11）}

頸部に対する手術は52例に施行され，全ては初回原発 巣手術施行（53例）時に同時に行われた。術式は, リン パ節摘出術，上頸部郭清術あるいは全頸部郭清術が行わ れていた。このうち原発巣同側に対する上頸部郭清術が 31 例 $(59.6 \%)$ で，両側同時施行例を合せると36例 (69.2 \%) と最も多く選択されていた，N分類別にみると，N0 症例38例中 34 例 $(89.5 \%)$ に頸部に対して手術が施行さ れており，その内訳は，リンパ節摘出術 6 例，上頸部郭 清術 28 例（患側のみ 25 例, 両側 3 例）が子防的頸部郭 清術として施行されていた。また，N1症例11例中 5 例 $(45.5 \%), \mathrm{N} 2$ 症例 8 例中 6 例 $(75 \%), \mathrm{N} 3$ 症例 7 例 中 7 例 $(100 \%)$ に原発巣手術と同時に上頸部または全頸 部郭清術が施行されていた。

\section{0. 頸部リンパ節転移の臨床診断と組織診の比較（表} 12)

頸部に対しては52例に外科手術が施行され, 病理組織 診 $(\mathrm{pN})$ と臨床診断（N)との正診率を検討した。臨木

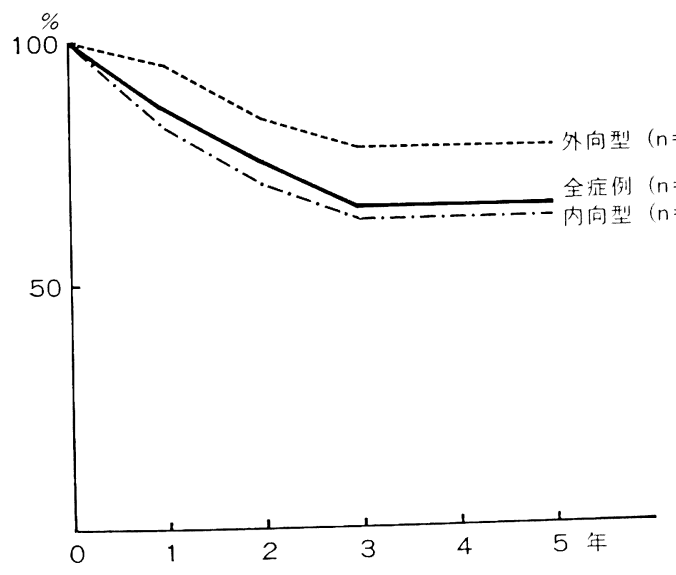

図 3 発育様式別累積生存率
的に頸部転移を認めなかった $\mathrm{N}$-症例 34 例のうち，4例 に病理組織学的転移 $(\mathrm{pN}+)$ を認め, 正診率は88.2\%で あった。 また逆に $\mathrm{N}+$ と臨术䛦断した18例のうち, pNであったのは8 例あり, 正診率は55.6\%であった。全体 の頸部転移に対する正診率は52例中40例て76.9\%であっ た.

\section{1. 治療成績}

治療成績を唡討するため，1986年（昭和61年）12月 日現在での生存調査を行い, 累程生存率を求めた。

今回の研究対象亡した舌癌 1 次症例 64 例全体の累積生 存率は，1年 $87.7 \%, 3$ 年 $65.6 \%, 5$ 年 $65.6 \%$ であっ た。これらをさらに以下の各分類を行い，それぞれの生 存率を算出した。

表 11 頸部に対する手術の術式別

\begin{tabular}{|c|c|c|c|c|c|c|}
\hline \multirow[b]{2}{*}{$\begin{array}{l}\mathrm{N} \\
\text { 分類 }\end{array}$} & \multirow{2}{*}{$\begin{array}{l}\text { リン } \\
\text { 擳 } \\
\text { 摘出 }\end{array}$} & \multicolumn{2}{|c|}{ 上頸部郭清 } & \multicolumn{2}{|c|}{ 全䫓部郭清 } & \multirow{2}{*}{ 計 } \\
\hline & & 両側 & 患側 & 対側＋患側 & 患側 & \\
\hline No & 6 & 3 & 25 & & & 34 \\
\hline N1 & & & 4 & & 1 & 5 \\
\hline N2 & & 1 & 0 & 1 & 4 & 6 \\
\hline N3 & & 1 & 2 & 1 & 3 & 7 \\
\hline 計 & 6 & 5 & 31 & 2 & 8 & 52 \\
\hline
\end{tabular}

表 12 頸部転移に対する臨床䛦断と組織診との比較

\begin{tabular}{c|c|c|c}
\hline $\mathrm{N} \quad \mathrm{pN}$ & $\mathrm{pN}-$ & $\mathrm{pN}+$ & \\
\hline $\mathrm{N}-$ & 30 & 4 & 34 \\
$\mathrm{~N}+$ & 8 & 10 & 18 \\
\hline & 38 & 14 & 52 \\
\hline
\end{tabular}

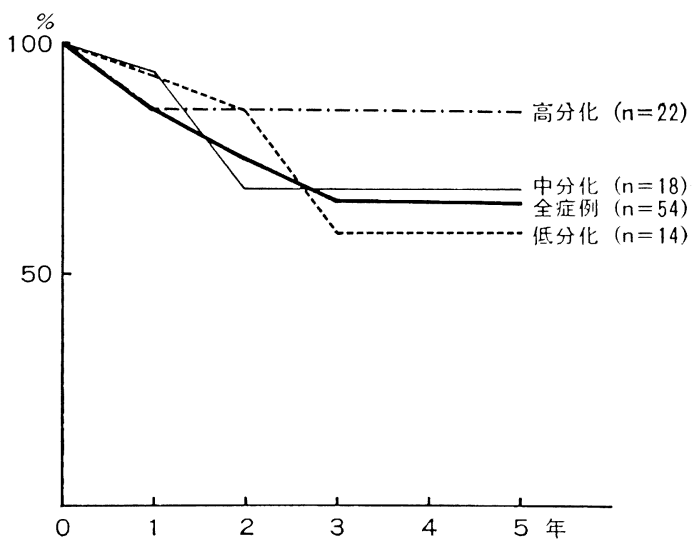

図 4 分化度別累皘生存率 


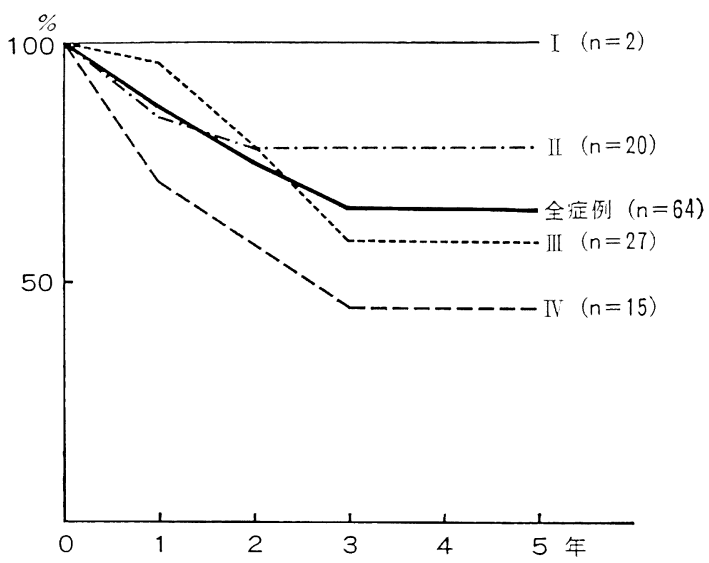

図 5 Stage 別累䅪生存率

i）発育样式別累積生存率（図 3)

腫瘍の発育椂式別の累積生存率をみると, 外向型発育 症例（22例）の 1 年累精生存率は $95.1 \%, 5$ 年で $77.2 \%$ であったのに対し, 内向型発育症例（42例）は 1 年累積 生存萃 $82.3 \%, 5$ 年では63.0\%であり, 外向型発育症例 の方が予後良好であった。

ii) 組織学的分化度別累積生存率（図 4)

組織学的分化度を検索可能であった54例について，累 積生存率を検討したところ 1 年累積生存率では中分化型 (18例) $93.6 \%$, 低分化型 (14例) $92.9 \%$, 高分化型 (22 例） $85.4 \%$ の順で，共に高い生存率であったが， 3 年以 後の累積生存率では高分化型 $35.4 \%$, 中分化型 $68.1 \%$, 低分化型 $59.8 \%$ の順之なり, 分化度の低い汪ぞ累積生存 率も低くなる倾向がみられた。 また，中分化型では 1 年 と 2 年の間に, 低分化型では 2 年と 3 年の間に累積生存 率の大きな差が珰められた。

iii) Stage 別累積生存率 (図 5 )

Stage 分類に累皘生存率をみると, Stage I （2 例） では 5 年累積生存率は 100\% と良好であった。

1 年累䅠生存率では Stage III (27例) $96.1 \%$, Stage II (20例) $84.2 \%$, Stage IV (15例) $70.4 \%$ の順である が, 3 年以後の累䅡生存率では, Stage II $78.0 \%$, Stage III 58.3\%, Stage IV 44.5\%と, Stage が進む活ど生存 率の低下をみた。

\section{iv) 治療法別累䅡生存率 (図 6)}

治撩法別に累程生存率孝及ると，1年累積生存率では 手術療法主体の $\mathrm{S}$ 群（6 例）は100\% と良好であり作用 療法の $\mathrm{S}+\mathrm{R}$ 群 (47例) $90.9 \%$, つついて放射線療法主 体の R 群（10例） $78.9 \%$ の順であった。 2 年以後の累積 生存率は S + R 群, $\mathrm{S}$ 群, R 群の順侅值を示した。 5 年累皘生存滴は， S + R 群が73.9\% と全症例 (64例) の 65.6\%を上水った，S 群は，55.6\%，R群は35.1\%と

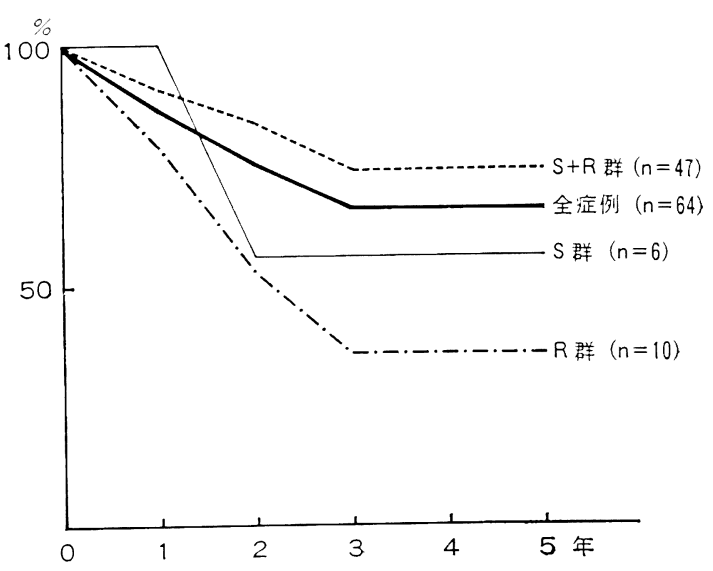

図 6 治療法別累積生存率

低い值を示した。また， $\mathrm{S}$ 群に関しては， 1 年と 2 年以 後の累積生存率 $(100 \% \rightarrow 55.6 \%)$ にかなりの差がみられ た。

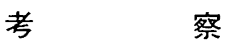

舌は䫇口腔領域において悪性腫場の発生頻度の高い部 位であり，過去の主な検討 ${ }^{3 \sim 6)}$ でも同様の 報告がなされ ている。当科での過去10年間に打ける頸口腔領域の悪性 腫瘍に関する統計学的観察》)では，上下頭を合せた歯肉 部に最も多く，次いで舌に多く認められた。ちなみに今 回の研究対象期間とした1973年 1 月から1985年12月まて の13年間での悪性腫瘍患者総数は 305 例で，そのらち舌 癌患者数は81例と $26.6 \%$ を占めていた。

今回の検討では, 男女比は $1.2: 1$ で, 斉藤8) と同率 であり, 砂川ら ${ }^{9)} 1.3: 1$, 草間ら ${ }^{10)} 2.3: 1$, Frazel ${ }^{111}$ 3. 5:1 とそれらの報告では男性が，多い傾向にあるが， 当科ではその差はわずかであった。

年秢別では, 男性については30歳代より急増し50歳代 をピークとし，加秢にしたがい徐々に減少しているのに 対して，女性では50〜70歳代に集中していた。諸家の報 告 ${ }^{5,8,9)}$ では男女いずれも50〜60歳代が多いとしており, 本統計では, 男性がやや若く（平均年秢 51.5 藏），女性 (平均年秢 56.7 歳) は汪注平均であった。竹田ら ${ }^{12}$, Martin ${ }^{13)}$ は, 舌癌は若年者にも少なくないとして拈り, 本統計では10歳代にはみられなかったが，20歳代が 4 例 であり，同時期の当科で扱った罘口腔領域癌患者の 20 歳 代がすべて舌に認められていることから，舌における若 年者の癌発生傾向は高いものと考学られた。

初発症状では, 疼痛が $45.3 \%$ を占め最も多く, 腫脤, 瀆瘍形成の順て続いた，堀ら ${ }^{6)}$, 草間ら ${ }^{10)}$ も同様の傾向 を報告している，可動性を有する舌が，䠛窩の鋭端部， 
不良補経物などとの接触頻度も高いことから, 疼痛の中 でも接触痛が19例と初発症状の $29.7 \%$ を占めていた。口 腔癌の発生と義歯, 補綴物などとの関連については, 清 水 ${ }^{14)}$ は91症例の5ち63.9\%になんらかの関連がみられた とし、そのなかで舌が最も関連頻度の高い部位であると 報告している。また, Vogler ら ${ }^{15)}$ は義菌と発癌との関連 は結論つけられないとしているが, 他報告では Martin ${ }^{13)}$ $10 \%$, 山下 ${ }^{16)} 40 \%$, 後藤 ${ }^{17)} 86.1 \%$ と数值に幅があるが, 今回の著者らの調査からも，それらの間になんらかの関 連があることが示唆された。

初発症状を自覚して当科来院までの期間は 3 か月以内 までが $48.4 \% ， 6$ か月までに71.9\%が来院しており，他 報告6,18) と注同様の傾向がみられた。また当科来院ま での経路では，39.1\%が畨科医師よりの紹介で最も多い ものの, 偶山ら ${ }^{19)} 70.9 \%$, 清水 ${ }^{20)} 69.5 \%$ とは大きな差 を認めた。一方, 患者自らが直接来院したもの $25 \%$, 他 科よりの紹介が $35.9 \%$ と高値を示しており, 当該地域に おける口腔外科を標榜する当科への理解が深まっている ものとも考光られた。

発生部位では舌縁が $87.5 \%$ と大部分を占め, 諸家の報 告 $\left.{ }^{8}, 10,17\right)$ 之同様の傾向がみられ，左右差を特に認めない のも同様であった。

病理組織型別では，64例中63例の98.4\%が扁平上皮癌 で占められており，従来の報告 $6,8,10,11,16)$ と一致した。 また一般に扁平上皮癌は分化度が高い傾向にあり, 中で も特に舌は頭頸部領域の他部位と比べても, 高分化型が 高頻度にみられるといわれている ${ }^{21 \sim 23)}$ しかし，本統 計での舌扁平上皮癌の分化度の判定では, 高, 中, 低分 化型の頻度順であったのは，他報告と同様であるがその 比率は接近する傾向にあった。

T分類では T2: 50.0\%, T3:42.2\%, T1:7.8\%の 順でT4は認めて抢らず, T2 が半数を占め, 他報告 9,10 , 12,18) と比べると, T 1 症例が少なく, T $2, \mathrm{~T} 3$ 症例が大 部分を占めているのが特徽的であった。

N分類については, 初診時頸部リンパ節転移を疑った $\mathrm{N}+$ 症例は64例中26例で40.6\% と高率であり，従来より 舌癌症例では所属りンハ節転移率が高いとする報告が多 く, Spiro $^{24)} 38.4 \%$, Frazell ${ }^{11)} 40 \%$, 斉藤 ${ }^{8)} 53.0 \%$, 岩井ら ${ }^{25)} 73.7 \%$ と高頻度の転移梁の報告をしている。 転移率は $\mathrm{T}$ の進行に比例する報告6,26) 女又られるが, 本 統計では，T2，T3に症例の片笴りがあるためか， T1： 5 例中 3 例 $(60.0 \%), \mathrm{T} 2: 32$ 例中 12 例 $(37.5 \%), \mathrm{T} 3$ : 27 例中11例 $(40.7 \%)$ と特に関連はみられなかった。

Stage 分類では, Stage III $42.2 \%$, Stage II $31.3 \%$, Stage IV 23.4\%, Stage I 3.1\%であり, 進展症例をや や多く認めた。

舌癌は, 口腔外科のみならず耳鼻咽喉科, 放射線科, 外科などで扱われ，またその施設や治療に当る医師によ りその治療法は画一的でなく，その治療成績については
一概に評俩するのは難しい，諸家の報告の中でも竹田 $5^{12)}$ は $90 \%$ 以上の舌癌症例に放射線治療を, また中田 $5^{27}$ は $84.4 \%$ の症例に施行している. 手術的治療を多く 行っていると報告している草間 ${ }^{10)}$ についてもR群54.4 \%で, S + R 群を加えると63.1\%と放射線治療の割合は 大きい，現在の他施設からの報告では舌の機能を考虑し て放射線治療を第一選択にする傾向が多いように思觉 る。当科での一次治療は，R群はわずかに10例(15.6\%) であり，大部分を占めたのが $\mathrm{S}+\mathrm{R}$ 群の64例中47例(73.4 \%) であった。 R群と S + R 群を加えると $89.0 \%$ とな り，他報告との放射線治療頻度は近くなるが，当科での $\mathrm{S}+\mathrm{R}$ 群は47例中45例までが術後の外照射であることか ら主体となっているのは手術治療であったと考学られ る.今回の当科での治療法別累積生存率をみると, $\mathrm{S}+$ R群が 5 年で $73.9 \%$ と比較的良好な成績であった。一方 $\mathrm{S}$ 群は55.6\%，R群は35.1\%であり，必ずしも良好とは いえない。これらの対象症例についてみると, S 群 6 例 では Stage I， II の 3 例は手術治療のみにより局所制御 可能であり，経過良好であったが, Stage III, N V 3 例 は, 術中迅速および術後病理組織診により, 腫瘍摘出切 断端および周囲組織に悪性所見が認められなかったにも かかわらず，不幸な経過をたどった。またR群10例では， Stage III 6 例の5ち 3 例, Stage IV の 2 例については 全くの姑息的手段として放射線治療を施行しており, 残 りの Stage II， IIIの 5 例に対しては組織内照射法により 根治的治療を目指したが経過は必ずしも満足のいくもの ではなかった。 S+R群47例は Stage I を除く各Stage に最为多く選択されていた。

術式別では, 頸部郭清術に連続して下䫀骨舌側骨膜の みを切除し, 下顎骨を保存し, 口腔内の原発巣を摘出す 万 pull through 手術 $\left.{ }^{4}, 28,29,40\right)$ が手術施行症例の半数以 上の $52.8 \%$ 占め, 当科に拈外る舌癌の基本的外科手術 術式となっている. pull through 手術は原発租である舌 および口底, 頸部組織を一塊として摘出するため, 術後の 頸部転移の予防には有効であると考无る。ちなみに, 185 例の舌癌に対して部分切除術を積極的に行った Spiro ${ }^{24)}$ は, 5 年粗生存率を $62.1 \%$ と報告し, 原発䉾制御率は Stage I 85.1\%, Stage II 77.0\%, Stage III 50.0\% とほ ほ良好であったが，術後頸部転移を認めたものが Stage I $29.1 \%$, Stage II $42.9 \%$, Stage II $77.0 \%$ と高率で あったと報告している。舌に対与る単独手術による機械 的刺激は所属リンパ節への転移の原因とも考光られ, 基 本的には同時期手術が選択されるべきである5。

最近は術後の放射線外照射では，腫瘍制御が困難で， 患者の免疫力を低下させるだけであり，進展例に対する 姑息的な意義しか認められないと否定的な考えも多い. 事拣当科においても, Stage III, IV症例の5ち, 術後経 過不良症例に刘して外照射を姑息的な治療として行った 症例も多い。しかし, 手術治療単独施行のS群よりも放 
射楾治療を加えた $\mathrm{S}+\mathrm{R}$ 群の方が生存率は高いことか ら，原発楽制御には効果的であったと考えられた。また， 外照射も組織内照射と組又合せることにより，ある程度 の成績向上が期待でき, 特に T3 群においての外照射の 役割は大きいとの報告 ${ }^{30}$ もあり，今後共進展例に対する 治療法として手術治療法と共に用いても良いと考える。

頸部に対しては，64例中52例 $(81.3 \%)$ に手術を行っ た. N0 症例 6 例にリンパ節摘出術を施行しているが, 術中の病理組織診断で転移を認めた場合は, 上頸部，ま たは全頸部郭清術が適応となった。 N0 症例38例の5ち 28 例 $(73.7 \%)$ に対して上頸部郭清術を施行しており, リン八節摘出術を加えると $89.5 \%$ の高率であった。予防 的頸部郭清術については，現在なお意見の分れるところ である.Jesse ${ }^{31)}$ は, 521例の口腔癌についての予防的頸 部郭清術の検討では，わずか $2.0 \sim 5.5 \%$ 生存率向上を みるだけで，手術の risk を考え合せると否定的である としている。 また，予防的頸部郭清術に対して否定的な 意見としては，1. 原発巣を完全に制御できていない間に リンパ節除去は免疫力低下となる，2. occult metastasis に対しては放射線治療が効果的である，3. 慎重な経過観 察により, 頸部転移が臨床的に診断した時点で十分外科 的処置が可能である，など27,32,33)が考えられる。しかし Johnson ${ }^{34)}$ は T1 N0 症例に対しても積極的に頸部郭清 術を行うべきであるとし，Whitehurst ${ }^{35)}$ は N0 症例で あってもTの stage により頸部郭清術の必要性があると している。当科では1. 予防的頸部郭清術を行った $N 0$ 症 例においても, 少なからず病理組織学的に転移が認めら れている $(11.8 \%), 2$ occult metastasis の対処として, 3. 頸部転移の骖断は触診に頼られ必ずしも的確性を欠 く，4.転移桨が大きくなると頸部郭清術が困難となる。 5. 舌癌では頸部リンハ節転移率が他部位に比べて高い, なとから䅡極的に予防的頸部部清術を選択して良いと考 えている。

橮部転移の診断は，( $\mathrm{T}$, 超音波誩断などの䛦断能力 が向上してきたとはいえ，今た触診に委小られており， また臨床経験による診断能力の差は認めざるをえない. 臨床骖断と病理組織学的診断との比較の検討では, 初診 時に頸部りン・節転移 $N+と$ 診断し, 頸部鄚清術後の病 理組織学的診断でも $\mathrm{pN}+$ であった正骖率は $12.9 \%{ }^{36)}$, $75 \%{ }^{10)} ， 79 \%{ }^{37}$ の報告があり，それに比べNーと診断後 $\mathrm{pN}$-であった正諩率は74. $2 \%^{36)}, 88.9 \%{ }^{10)} 95 \%{ }^{37}$ と より高い絬果となっている。当科での正嗙率も前者 55.5 $\%$ (18例中 10 例)，後者は88.2\%（34例中 30 例）て同様 の傾向かみられ触診による頸激転移を疑った場合には， 複数の医師による触診の習慣化とともに触診技術の向上 に努めなければならないことを再認識した。

全64症例の累积生存率は 1 年 $87.7 \%, 5$ 年 $65.6 \%$ であ った。これまで報告されている生存率は，1960年代では 5 年累䅡生存摔て Frazell ら ${ }^{11)} 35.4 \%, \mathrm{Ash}^{35)} 34.8 \%$,
Flamand ${ }^{39)} 47.3 \%$ と低率であったが，最近では草間ら ${ }^{10)}$ $60.5 \%$, 竹田 ${ }^{12)} 61.4 \%, \mathrm{Spiro}^{24)} 62.1 \%$, 工藤 ${ }^{36)} 66.1 \%$ と目覚ましい向上がみられており，当科の成績もおおむ ね満足のいくものであった。

Stage 別では, Stage の進行につれ予後不良であり， 5 年累積生存率は Stage I 100\%, Stage II 78.0\%, Stage III 58.3\%, Stage IV 44.5\%であった，最近の他 の報告をみると，手術治療を主に行った Spiro ${ }^{24)}$ は 5 年 粗生存率で Stage I 69.2\%, Stage II 52.7\%, Stage III 36. $6 \%$ ，また放射線治療を主体とした堂原 ${ }^{40)}$ はStage I $66.7 \%$, Stage II $45.6 \%$, Stage III $50 \%$, Stage IV $20 \%$ であり，併用療法ではあるが， R群の多い中田 ${ }^{27)}$ Stage I $76.5 \%$, Stage II $61.5 \%$, Stgae III 23.1\%, Stage IV 0\%, S 群の多い草間ら ${ }^{10)}$ は 5 年累積生存率で Stage I $94.7 \%$, Stage II 69\%, Stage III 47.9\%と, やはり Stage の進行につれ予後不良の傾向がみられた。

発育様式別累積生存率の過去の報告をみると，小浜 ${ }^{41}$ の口腔粘膜扁平上皮癌94例に氺ける検索では，7年粗生 存率で外向型は89\%, 内向型で75\%, また砂川ら ${ }^{9)}$ は確 定生存率で外向型83.3\%に対して内向型27.3\%と明らか な差を報告しており，本統計でも5 年累積生存率で外向 型77. $2 \%$, 内向型 $63.0 \%$ と同傾向がみられ, やはり浸潤 傾向のみられる内向型は外向型に比べ低い生存率を示 し，予後不良であった。臨床所見の分類ではあるが，原 発宩切除の際には十分考虑する必要があると思われた。

病理組糡学的分化度別の 5 年累積生存率では, 高分化 例が最も成績が良く，中，低分化例の順に不良であっ た。以前より, 病理組織学的所見と臨床経過を関連つけ る研究 ${ }^{41 \sim 47}$ は数多くなされている。著者ら ${ }^{45)}$ は, Willén の分類方法 ${ }^{46}$ に従って下䫇歯肉扁平上皮癌 38 症例の初診 時生榆標本について病理組織学的恶性度を評価した結 果, 頸部リン八節転移 $(\mathrm{pN})$ に対して, $\mathrm{pN}+$ 群は浸潤 様式と浸潤程度がより高い傾向にあり， $\mathrm{pN}$ - 群は低覀 性群に多く認められたことを報告している。また，舌扁 平上皮癌 47 症例について同様に検討した結果 ${ }^{47)}$, 頸部り ンパ節転移群には同様の傾向がより強く認められたのに 加え，腫序の制御についても組織学的悪性度が高いほと 非制御例が有意に高い傾向であった。初診時生検標本は 腫瘍とその周囲組䅧の一部に過きなく，その組織像に著 しい差がみられることは明らかであり，ての一部で全体 の組織学的性格を把握与るのは無理がある。しかし，分 化度を含さ病理組織学的覀性度が, 頸部リンパ節転移の 子測，局所制御の難易度を推察し5る資料になることは 明らかであり，治療法の選択，特に予防的頸部郭清術の 選択に対しては十分参考とすべきであろう。

結語

京都大学医学部附属病院口腔外科を受診した舌癌 1 次 
症例64例について臨床統計的研究を行い，以下の結果を 得た。

1）男女比は $1.2: 1$, 平均年㱓 53.8 藏であった。初 発症状は疼痛が $45.3 \%$ で多く，3 月月までに $48.4 \%$ が来 院しており，歯科医師からの紹介が多かった。

2 ）発育様式では内向型が多く，組織型では1例を除 く63例が扁平上皮癌であった。 T分類では T3が50\%を 占め，N分類では N0が59.4\%で，病期別では Stage III， Vで65.6\%と進展例が多く占めた

3）治療法別では Stage II， III，IVで手術治療に術後 照射を加えた群が全体の73.4\%を占めた。

4 ）原発单に対しては 64 例中 53 例に手術治療を施行 し，その術式は pull through 手術が56.6\%と多かった。

5 ) 手術施行 53 例中 52 例に同時頸部手術を行ってお り，頸部転移の臨床診断と組織診の正診率は76.9\%であ った。

6 ） 64 例の 5 年累積生存率は，65.6\%であった。

7 ） 5 年累積生存率は分化度が低くなるに従い，また Stage が進むにしたがい低下した。また，発育様式別で は外向型が 5 年が $77.2 \%$ で内向型より良好であった。

8 ）治療法別 5 年累積生存率では，S+R群が73.9\% に対し，S 群は55.6\%，R群35.1\%と低く，手術と放射 線治療との併用療法が有効であった。

本論文の要旨は, 昭和 61 年 10 月 15 日の第 31 回日本口腔 外科学会粉会（久留米市）にて発表した。

\section{引用 文 献}

1) UICC: TNM-Classification of malignant tumors. 3rd Ed, UIC'C, Geneva, 1978, p 2326.

2) 热津邦雄：口腔癌の現況とその動向(上)一自験 例考中心に一。绦界展望 47：357-367 1976.

3) Arther, K. and Farr, H.W.: Prognostic significance of histologic grade in epidermoid carcinoma of the mouth and pharynx. Am J Surg 124: 489-492 1972.

4) 富田喜内, 戸塚靖則：口腔癌の基礎と臨床, Oncologia 8: 79-97 1984.

5）山城正宏，藤井信男，他：口腔領域覀性腫㾓の 臨床病理学的研究第 2 報過去 10 年間の実態と 治療成績。口科誌 34：357-363 1985 .

6）堀みどり，三吉康郎，他：当教室20年間の口 腔悪性腫瘏の臨床統計的钼察。耳多臨床 74: 1025-1037 1981.

7）足立尚，飯塚忠彦，他：当科出计る過去 10 年間の顎口腔領域悪性腫場の臨休統計的観察 日口外誌 33：1442-1449 1987.

8) 斎藤 等, 任藤文彦, 他 わが教室 16 年間の舌 覀性腫序の統計的微察。耳啹 45：29-36 1973.

9) 砂川元, 山城正宏, 他. 口腔領域恶性腫序の
郘床病理学的研究第 4 報舌癌について。只科 誌 35：873-880 1986.

10）草間幹夫，宇津宮幸正，他口腔覀性腫瘍の臨 床的研究 1) 舌恶性腫瘍について。日口外誌 31: 126-138 1985.

11) Frazell, E.L. and Lugas, J.C. Jr.: Cancer of the tongue. Report of the management of 1, 554 Patients. Cancer 15: 1085-1099 1962.

12）竹田干里, 熟津邦雄：舌がん。癌の臨床 20 : 301-310 1974.

13) Martin, H.E.: Cancer of the tongue. Arch Surg 41: 888-937 1940.

14）消水正嗣：口腔癌と我㳡・補経物などとの関連. 㳡界展望 37：25-38 1971.

15) Vogler, W.R., Lioyd, J.W. et al.: A retrospective study of etiological factors in cancer of the mouth, pharynx, and larynx. Cancer 15: 246-258 1962.

16）山下久雄, 網野三郎, 他: 舌癌の放射線治療. 癌の臨休 7: 195-204 1961.

17) 後藤敏郎, 楖野権次郎, 他: 舌癌の研究一臨床 的観察の部一 日耳鼠 67：622-6301965.

18）本田学, 竹内和郎, 他：当教室に求汁子舌悪 性腫序の統計的钼察。耳舆臨床 78: 969-975 1985.

19）亀山忠充, 竹中将純, 他：当科にお汁る過去 10 年間の悪性腫瘍患者の臨床統計的観察。日口外 誌 29: 1738-1745 1983.

20）清水正嗣：口腔癌の診断と治療に方ける迷科医 師の責任と処置。崊界屋望 26：953-962 1965.

21）坂本忠幸, 宮田和幸, 他：口腔領域疾患の臨床 病理学的検討第 5 報扁平上皮癌につい二。日 口外誌 26：1023-1029 1980.

22) 坂本穆彦, 茅野照雄, 他: 舌扁平上皮癌の早期 浸潤。癌の臨床 28: 11-15 1982.

23) Batsakis, J.G.: Tumors of Head and Neck. 2nd Ed, Williams \& Wilkins Co, Baltimore, 1979, p 144-176.

24) Spiro, R.H. and Strong, E.WI. Epidermoid Carcinoma of the mobile tongue; Treatment by partial glossectomy alone. Am J Surg 122: 707-710 1971.

25）岩井一, 田村症已, 他：舌癌の手術的治療に 対方古考察。耳息臨床 60：25-301967.

26）森田浩二，林繁次郎，他：舌癌の放射線治療 成繢。癌の臨床 23: 511-518 1977 。

27）中田将風，岸本昭罳，他：舌癌の治療成繦。医 療 37: 381-386 1983.

28）田代英雄：舌癌。潾科シャ一ナル 14：655-662 1981.

29）大谷隆沿, 瞏山昇, 他図説口腔外科手術 学 中巻, 医蔌薬出版, 東京, 1988, 484-485頁,

30）重松 康：舌癌の治療避択一特に放射線治療に ついて一。耳是臨床 70：889-891 1977.

31) Jesse, R.H., Barkley, H.T., et al.: Cancer of the oral cavity. Is elective neck dissection 
benetical ?. Am J Surg 120: 505-508 1970.

32) Vandenbrouck, C., Sancho-Garnier, H., et al.. Elective versus therapeutic radical neck dissection in epidermoid carcinoma of the oral cavity. Cancer 46: 386-390 1980.

33）小野 勇, 傿津邦雄, 他：舌癌治療に打忛万頸 部郭清術の評価。癌の臨床 26：123-130 1980.

34) Johnson, M.J.T., Leipzig, B., et al. . Management of $\mathrm{T}_{1}$ carcinoma of the anterior aspect of thetongue. Arch Otolaryngol 106: 249-251 1980.

35) Whitehurst, J.O. and Droulias, C.A.: Surgical treatment of squamous cell carcinoma of the oral tongue. Arch Otolaryngol 103: 212-215 1977.

36）工藤啓吾, 瀬川 清, 他：舌癌 31 症例の治療成 績に関する検討。日口外誌 32：211-216 1986.

37）三橋麗子：頭頸部癌の頸部転移についての臨床 的病理組織学的研究.日耳鼻 71:621-639 1968.

38) Ash, C.L.: Oral cancer. A twenty-five year study. Amer J Roentgenol 87: 417-422 1962.

39) Flamand, R., Hayem, M., et al.: Cancer of the tongue. A study of 904 cases. Cancer 17: 377 -385 1964.

40）堂原義美，杉原一正，他：舌癌の放射線治療成
績の検討。口科誌 30：24-33 1980.

41）小浜源郁：口腔癌の化学療法効果に関方る臨 床, 病理, 細胞性免疫学的研究一特に臨床病理 学的恶性度とブレオマイシン効果扣よび予後に ついて。 口科誌 33：672-698 1984.

42) Mendelson, B.C., Woods, J.E., et al.: Neck dissection in the treatment of carcinoma of the anterior two-thirds of the tongue. Surg Gynecology \& Obstetrics 143: 75-81 1976.

43) 藤谷哲造, 志水雄輔, 他 : 舌癌の病理組織学的 悪性度と放射線治療後の臨床経過との関連，癌 の臨床 24：661-665 1978.

44) 花沢 秀: 舌癌に扣ける組織学的悪性度(Willen 分類変法）と頸部リンパ節転移との関連性。日 癌治 21：34-41 1986.

45）横江義彦，足立尚，他：下顎速肉扁平上皮癌 の臨床病理学的研究一初診時生検病理組織と局 所制御, 頸部転移ならびに予後との関連につい て一。 日外誌 35：242-248 1989.

46) Willen, R., Nathanson, A., et al.: Squamous. cell carcinoma of the gingiva. Histological classification and grading of malignancy. Arch Otolaryngol 79: 146-154 1975.

47) 足立尚, 野瀬将洋, 他: 舌癌の病理組織学的 悪性度と臨床経過(抄)。口科誌 36：1021 1987 。 